\title{
YÜKSEKÖĞRETIM VE İNSAN HAKLARI: BİTMEYEN BİR TARTIŞMA
}

Doç Dr. Nezir Akyeşilmen*

\section{ÖZET}

Eğitim hakkı hem ulusal hem de uluslararası düzeyde son y1llarda ana günden konularından birisi olmayı başardı. Uluslararası insan hakları belgeleri, eğitimi temel bir insan hakkı olarak tanımlarken, verilecek eğitimin de insan hakları ilke ve prensiplerine uygun olması gerektiğini belirtmektedirler. Fakat yükseköğretimin evrensel bir insan hakkı olup olmadığı konusunda literatürde derin görüş ayrılıkları var. Kimisi yükseköğretimi bir insan hakkı olarak tanımlarken, başkası bunun tartışmalı olduğunu ileri sürebilmektedir. Söz konusu tartışma sadece eğitim hakkın tanımı ile sınırlı olmayıp doğası, kapsamı ve niteliğiyle de ilgilidir. Bu çalışma yükseköğretim ve insan hakları bağlamında birkaç temel soruya cevap aramaya çalışmaktadır: Yükseköğretim evrensel bir insan hakkı mıdır? Hak-temelli bir yükseköğretim nasıl olmalıdır? Üniversitede akademik özgürlük ve kurumsal özerklik bu tartışmanın neresinde yer almaktadır? Bu çalışmanın ulaştığı veriler dikkate alındığında, akademik özgürlüğün üniversitelerde önemsendiği fakat yeterince tartışılmadığı, çalışılmadığ ve öncelenmediği açıkça görülecektir. Bu kısa çalışma, söz konusu sorunların aşılması için bir takım öneriler sunmaktadır.

Anahtar Kelimeler: Eğitim Hakkı, Yükseköğretim, İnsan Hakları, Akademik Özgürlük, Katılımcılık

\section{HIGHER EDUCATION AND HUMAN RIGHTS: UNENDING DISPUTE}

\begin{abstract}
Right to education has succeeded to be one of the main agenda at both national and international levels in recent years. While international human rights documents accept education as one of the basic human rights, education also needs to be compatible with the human rights norms and principles. Yet there are sharply different approaches in the literature on whether higher education is a universal human right or not. Some consider it as human rights while some others claim that it's discussible. This discussion is not limited with definition of the right to education but also related to its nature, content and the quality. This paper tries to answer some basic questions on the relationships between higher education and human rights: Is higher education a universal human right? How does a rights-based higher education needs to be? Where do the academic freedom and institutional autonomy of university stand in this discussion? When the data accessed in this study are taken into consideration, it is clear that academic freedom is cared about, yet it is not adequately discussed, studied and prioritized. This piece of work comes up with some recommendations to overcome the mentioned problems.
\end{abstract}

Key Words: Right to Education, Higher Education, Human Rights, Academic Freedom, Participation

*Selçuk Üniversitesi Uluslararası İlişkiler Bölümü Öğretim Üyesi, nezmen@yahoo.com 


\section{GíRiş}

Eğitim ve insan hakları arasındaki ilişki oldukça komplikedir. Eğitimin, özellikle yükseköğretimin, literatürde insan hakkı olup olmadığı tartış1lırken, başta Evrensel İnsan Hakları Beyannamesi (EİHB-1948) olmak üzere, Avrupa İnsan Hakları Sözleşmesi (1952) 1 No'lu Protokolü, Eğitimde Ayrımcılığa Karşı Sözleşme (1960), Uluslararası Ekonomik, Sosyal ve Kültürel Haklar Anlaşması(1976) ve Çocuk Hakları Sözleşmesi gibi uluslararası başlıca insan hakları belgelerinde bir insan hakkı olarak tanımlanmaktadır. Eğitim hakkını ve içeriğini detaylı bir şekilde tanımlayan EİHB (26. madde), eğitimi bir insan hakkı olarak tanımladıktan sonra, verilecek eğitimin nasıl olması gerektiğini de detaylıca açıklamaktadır:

1. Herkes, ĕgitim hakkına sahiptir. Ĕ̈itim, en azından ilk ve temel öğrenim aşamalarında parasızdır. İlköğretim zorunludur. Teknik ve mesleki eğitim herkese açıktır. Yüksek öğrenim, yeteneğe göre herkes için eşit olarak ulaşılabilir olmalıdır.

2. Eğitim, insan kişiliğinin tam geliştirilmesine, insan haklarına ve temel özgürlüklere saygıyı güçlendirmeye yönelik olmalıdır. Ĕgitim, bütün uluslar, ırklar ve dinsel gruplar arasında anlayış, hoşgörü ve dostluğu yerleştirmeli ve Birleşmiş Milletlerin barışı koruma yolundaki etkinliklerini güçlendirmelidir.

\section{Ana-babalar, çocuklarına verilecek eğitimi seçmede öncelikli hak sahibidir.}

Eğitim ve insan hakları arasındaki tartışmalı ilişki şüphesiz ki tanımlamayla sınırlı değildir. İnsan hakları ruhsat niteliğinde olmasına rağmen -yani kişi isterse kullanır isterse kullanmaz- EİHB 26. maddesinin temel eğitimi zorunlu görmesi ayrı bir tartışma konusudur. Diğer taraftan eğitim hakkı, pozitif bir insan hakkı olarak sınıflandırılıyorken, negatif haklar gibi toplumun ivedi bir yükümlülüğü olarak kabul edilmesi, eğitim hakkını daha da karmaşık bir hale getirmektedir. EİHB 26. maddesi, yükseköğretim dahil, eğitimi bir insan hakkı olarak tanımlarken, verilecek eğitimin insan kişiliğinin tam geliştirilmesine, insan haklarına saygıyı ve küresel barışa hizmet edecek nitelikte olmasını da eğitim hakkının bir bileşeni olarak kabul etmektedir.

Felsefi açıdan eğitim hakkının bir insan hakkı olup olmadığı tartışılırken, yukarıda tartışıldığı gibi, hukuki anlamda bir hak olarak tanımlanması, uluslararası insan hakları belgeleriyle sabittir. Eğitim ve insan hakları bağlamında en tartışmalı konuların başında yükseköğretimin bir insan hakkı olup olmadığ1 gelmektedir. Kimisi, yükseköğretimin bireysel kazanç sağladığından kişiler maliyetini yüklenmeli derken, bunun bireysel değil kamu yararına olduğunu savunanlar ise, yükseköğretimin evrensel bir insan hakkı olarak tanımlanması gerektiğini ileri sürerler (McCowan, 2012:111). Fakat şu da bir gerçektir ki; kamu yararı bir insan hakları kavramı değildir. Aksine, insan haklarında öncelenen şey, kamu yararı değil, kişi yararı ile temel hak ve özgürlükleridir. İkisi arasında bir çatışma olması durumunda hükümetler insan haklarını sınırlandırma yoluna gitse de, insan hakları anlayışında ve felsefesinde öncelikli olan kişi hak ve hürriyetleridir. 
$\mathrm{Bu}$ makalede iki konu üzerinde durulacaktır. Birincisi, yükseköğretimin evrensel bir insan hakkı olup olmadığı uluslararası insan hakları belgeleri 1şığında irdelenecek ve ikincisi, insan haklarına uygun başka bir deyişle hak-temelli bir yükseköğretimin özellikleri tartışılacaktır.

\section{Yükseköğretim Bir İnsan Hakkı Mı?}

1888 yılında ilk defa bir kadın Britanya üniversitelerinde hukuk eğitimi almak için Oxford'da yeni kurulan Somerville Kolejine başvurdu. O kadın, Hindistan'ın ileri gelen bir ailesinden ve emperyal Britanyanın bir vatandaşl olan Cornelia Sorabji'dir. Somerville'nin diğer kadınları gibi, Sorabji de herhangi bir dini sınav ya da zorunluluğa tabi değildi. Fakat o zamanlar, 1920 yılına kadar kadınlar Oxford'a kabul edilmiyorlar ve diploma alamıyorlardı. Bu sınırlamaya ră̆men, Cornelia Sorabji hukuk sinavlarına erkeklerle beraber girebilmek için yetkililer nezdinde başarıl bir mücadele verdi. Fakat barolar da kadınları üyeliğe kabul etmedikleri için, ilk denemelerde avukat olma hakkı reddedilmesine rağmen, daha sonra Hindistan'da bu mesleği elde etmeyi başardl

(Osler, 2012: 295).

127 yıl önce meydana gelmiş olan bu kısa hikâyede başta ayrımcılık olmak üzere, eğitim hakkının (yükseköğretim hakkının) ihlali, cinsiyet ayrımcılığı, çalışma hakkının ihlali, eşitlik ve özgürlüklerinin yok sayılması, insanlık onurunun zedelenmesi gibi bir dizi kişi hak ve hürriyetleri yok sayılmaktadır. Sorabji gibi kişilerin onur ve hak mücadeleleri, insan haklarının bugünkü kapsamlı ve yaygın bir boyuta gelmesinde önemli rol oynamıştır. O gün cinsiyet temelli ayrımcılık nedeniyle yükseköğretim hakkından yoksun bırakılan Sorabji gibi, bugün de dünyanın çeşitli bölgelerinde başka tür ayrımcılıklarla insanlar bu haklarından mahrum bırakılabilmektedir. Fakat uluslararası insan hakları hukukunda yükseköğretimi de kapsayan eğitim hakkı evrensel bir insan hakkı olarak kabul edilmektedir.

İnsan hakları, insan olması hasebiyle herkesin eşit bir şekilde sahip olduğu ya da olması gerektiği, kişinin insanca yaşamasını sağlayan ve insanlık onurunu korumayı amaçlayan evrensel ve ahlaki normlardır(Madigan, 2004: 74-77; Haule, 2006:368).Bu çerçevede bütün insanlar insanlık onuru ve hakları bakımından eşit ve özgür doğarlar ( EİHB, Madde,1). Temelinde özgürlük ve eşitlik olan insan hakları kişiler açısından bir ruhsattır, kullanımı kişinin özgür iradesine bırakılmıştır. Kişi isterse haklarını kullanır, istemezse kullanmaz. Oysa 2009 yılında dünya geneline bakıldığında yükseköğretim çağında olup eğitim gören öğrenci oranı \%27'dir (Globalhighered, 2011). Cevabı bulunması gereken soru, geri kalan insanların \%73'nün tamamı ya da bir kısmı bu hakkını kullanmak istemiyor mu yoksa bu hakkını kullanamıyor mu? Yani iradesi dışında bu hakkından mahrum mu birakilmaktadır?

Yükseköğretim, başlıca uluslararası insan hakları belgelerinin eğitim hakkını düzenleyen maddelerinde hep zikredilmiştir. EİHB 26. maddesinin 2. fikrasında " Yükseköğrenim, yeteneğine göre herkes için eşit olarak ulaşılabilir olmalıdır" hükmü yer almaktadır. Aynı şekilde, Uluslararası Sosyal, Ekonomik ve Kültürel Haklar Sözleşmesinin madde 13-c fikrası da, "Yüksek öğrenim, özellikle başlangıçta verilecek ücretsiz geliştirme eğitimi gibi her türlü uygun vasitalarla, yetenek ölçüsüne göre herkesin eşit olarak yararlanmasına açık duruma getirilir" şeklinde düzenlenmiştir. Hem Beyanname hem de Sözleşme yükseköğretim ile ilgili hususları eğitim hakkı çerçevesinde değerlendirdiğinden 
yükseköğretimin evrensel bir hak olup olmadığı konusundaki tartışmaya 1şı tutmaktadır. Kısacası, başlıca uluslararası insan hakları düzenlemelerinde eğitim hakkı yükseköğretimi de kapsayacak şekilde düzenlenmiştir (Benedek, 2012: 43). Fakat insan hakları insan olmamız hasebiyle hiçbir ön şart aranmaksızın sahip olunan haklardır. Peki, yükseköğretim hakkından yararlanmak için yetenek ya da başka herhangi bir şart ileri sürülebilir mi? Bu sorunun cevab1 insan hakları kuşakları ya da gruplarında gizlidir.

\section{1. İnsan Hakları Gurupları: Ayrı Fakat Ayrılmaz}

İnsan hakları evrensel ve bir bütün olarak kabul edilmesine (Viyana Deklarasyonu ve Eylem Plan1,1993: Par. 5) rağmen, hakların niteliğinin daha iyi anlaşılabilmesi için literatürde farklı temellerde gruplandırılırlar. $\mathrm{Bu}$ çerçevede, ortaya çıkış ve gelişim tarihleri ve temellendirildikleri felsefi dayanaklarına göre dört kuşağa ve devletle ilişkilerine göre de negatif ve pozitif haklar şeklinde sinıflandırılırlar. 17. ve 18. yüzyıl liberal aydınlanmacı felsefeye dayalı haklar, kapitalist Batılı ülkelerin önceledikleri birinci kuşak haklar ya da Sivil ve siyasal haklar olarak tanımlanırken, 19. yüzyıl eşitlikçi sosyalist düşünceye dayalı haklar ise, Sosyalist ülkelerin daha çok önemsediği ikinci kuşak haklar ya da Ekonomik, sosyal ve kültürel haklar olarak kabul edilirler. Üçüncü dünya ülkelerinin desteklediği üçüncü kuşak haklar ya da uzlaşma hakları ve dördüncüsü, tartışmalı da olsa bazıları tarafından ileri sürülen bilişim ve iletişim hakları ve bazılarına göre ise bu kategorideki haklar genetik mühendisliği ile ilgili hak grupları daha çok 20. yüzyılda geliştirilmiştir (Pavel, 2012: 873-883; Cornescu, 2009).

\subsubsection{Birinci Kuşak Haklar ya da Negatif Haklar}

Birinci kuşak haklar 17 ve 18. yüzyıllarda gelişen liberal aydınlanmacı felsefeye dayanır. Devlete karşı bireyin özgürlüklerini merkeze alan bu haklar daha ziyade sivil ve siyasal hakları kapsamaktadır. Bu çağlarda devletin fazla müdahaleci politikalarını ve mutlak egemenlik anlayışını sorgulamaya başlayan filozoflar, yöneten-yönetilen ilişkisinde yönetilenin rızası ve haklarının korunması fikrini savundular. İktidar mutlakıyetçiliğinin sınırlandırılabilmesi, keyfiliğin ortadan kaldırılması ve yönetilenlerin rızasının yansıması olarak zamanla yönetime katılma hakkı ile ilgili siyasal haklar düşüncesi yaygınlaştı. Bireyin özerkliği, kendini etkileyen süreçlere katılım ve iktidarı sınırlandırma düşüncesi ile birlikte kişisel özgürlük ve bireyin devletin müdahalesinden korunması düşüncesi gelişti. Literatürde sivil ve siyasal haklar olarak tanımlanan bu haklara aynı zamanda özgürlük hakları ve liberal felsefeye dayandıkları için liberal haklar diyenler de vardır.

Farklı temellere dayandırılarak değişik isimler altında gruplandırılan birinci kuşak hakların devlet ile ilişkisi yönüyle negatif haklar da denir. Bu hakların özü “-den özgür olma"dır. Burada ifade edilen şey baskıdan, işkenceden, sınırlandırılmadan, yasaktan, ayrımcılıktan, dışlanmadan, adaletsizlikten, kölelikten, kendini ifade etmekten ve bütün bunları yapma gücüne sahip örgütlü yapı olan devlet'ten özgür olmadır. Başka bir ifade ile, birincil kuşak hakların en belirgin özelliği özgürlük fikridir(Sastry, 2011: 15-16). Bu haklar devlet müdahalesinin yokluğunu öngörür. Bu hak grubunun özü, devlet "gölge etmesin başka ihsan istemez" şeklinde formüle edilebilir.

Birinci kuşak haklar ya da negatif haklar başta Evrensel insan Hakları Beyannamesi (EİHB)'nin 3-21. maddeleri ve Uluslararası Sivil ve Siyasal Haklar Sözleşmesi (1976) ile 
düzenlenmiştir. Kişilerin eşit ve özgür bir şekilde bu haklardan yararlanması ve devletlerin bu haklara saygı göstermesi ve onları ivedilikle sağlaması gerekir. Uluslararası Sivil ve Siyasal Haklar Sözleşmesi'nin ikinci maddesi bu gerçeği şöyle ifade etmektedir:

1. Bu Sözleşme 'ye Taraf her Devlet kendi ülkesinde yaşayan ve yetkisi altında bulunan bütün bireylere irk, renk, cinsiyet, dil, din, siyasal ya da başka fikir, ulusal ya da toplumsal köken, mülkiyet, doğum ya da başka bir statü bakımından hiçbir ayırım gözetmeksizin bu Sözleşme'de tanınan hakları sağlamak ve bu haklara sayg göstermekle yükümlüdür.

2. Mevcut mevzuatta ve diğer yasal tedbirlerde henüz düzenleme bulunmayan durumlarda, bu Sözleşme'ye Taraf her Devlet, kendi anayasal kurallarına ve bu Sözleşme'nin hükümlerine uygun olarak, bu Sözleşme'de tanınan hakların uygulanmasını sağlamak bakımından gerekli olan yasama ve diğer tedbirleri almakla yükümlüdür.

Uluslararası insan hakları belgelerinde ifade edilen başlıca sivil ve siyasal haklar ya da özgürlük haklarından bazıları şöyle ifade edilmiştir (Donnelly, 1986: 607): Özgürlük ve güvenlik hakkı; yaşama hakkı; özel mülkiyet hakk1; yaşama hakk1; kölelik yasağı; adil yargılanma hakkı; işkence yasağ1; din ve vicdan özgürlüğü; ifade özgürlüğü; örgütlenme özgürlügü; seyahat hakkı; kişiliğinin tanınması hakkı; hukuk önünde eşitlik; seyahat hakkı; demokratik katılım hakkı ve iltica hakkı.

\subsection{2. İkinci Kuşak Haklar ya da Pozitif Haklar}

İkinci kuşak haklar 19. yüzyılda sosyalist gelenekten etkilenmiş, sanayileşme ve işçi sınıfının gelişmesi ve mücadelesi sonucu ortaya çıkmıştır. Sanayileşmeyle birlikte ortaya çıkan işçiler ve şehirlere yoğun göç sonucu artan işsizlik ve emek sömürüsü neticesinde artan gelir adaletsizliği, aşırı fakirlik ve yoksulluk beraberinde yeni ihtiyaçlar doğurmuştur. İnsanlık onurunu korumak için özgürlügün tek başına yeterli olmadığı, yeme, giyinme ve barınma gibi temel ihtiyaçların karşılanamaması ve insanlık onuruna yakışır bir hayatın sürdürülememesinin de insanlık onurunu zedelediği gerçeği fark edilmiştir. Bu haklar, temel ihtiyaçları karşılamaya yönelik olduğu için refah hakları olarak da adlandırılmaktadır ( Kara, 2014: 73-74). Diğer taraftan önemli bir kısmı sosyal adaleti sağlamaya yönelik haklar olması hasebiyle eşitlik hakları olarak da bilinirler.

Sosyal, ekonomik ve kültürel haklar olarak da bilinen bu hakların sağlanabilmesi için topluma pozitif bir sorumluluk düşmektedir. Birinci kuşak haklarda toplumun sorumluluğu sayg1 duyma ve koruma ile sınırlı iken, ikinci kuşak haklarda toplumun sorumluluğu maliyeti yüklenme şeklindedir. Bu hakların sağlanabilmesi topluma ya da devlete mali bir yükümlülük getirmektedir. Yani devletin pozitif bir yük yüklenmesi gerekmektir ki; bu nedenle bu haklara aynı zamanda pozitif haklar da denmektedir. Birinci kuşak hakların aksine bu hakların sağlanmasında devletin müdahalesi gerekmektedir.

$\mathrm{Bu}$ haklar genel olarak Uluslararası Sosyal, Ekonomik ve Kültürel Haklar Sözleşmesi (1976) ve Evrensel İnsan Hakları Beyannamesi(EIHHB)'nin 22-27. maddelerinde düzenlenmiştir. Uluslararası insan hakları belgeleri, birinci kuşak hakların tüm devletler tarafından herkes için eşit ve ivedilikle sağlanması talep edilirken, pozitif hakların her ülkenin kendi kaynakları mesabesinde ve tedrici olarak sağlanması talep edilmektedir. Bu durum 
Uluslararası Sosyal, Ekonomik ve Kültürel Haklar Sözleşmesi ikinci maddesinde şöyle ifade edilmiştir:

1. Bu Sözleşme'ye Taraf her Devlet, münferiden ve ekonomik ve teknik plan başta olmak üzere uluslararast yardım ve işbirliği yoluyla, mevcut kaynakların azamisini kullanarak, bilhassa yasal düzenleme suretiyle alınacak tedbirleri de içerecek şekilde her türlü $\quad$ uygun yöntem vasıtasıyla, bu Sözleşme'de tanınan hakların tam olarak kullanılmasını aşamalı olarak sağlamak amacıyla tedbirler almayı taahhüt eder[vurgu yazar tarafindan yapılmıştır].

2. Bu Sözleşme'ye Taraf Devletler, bu Sözleşme'de belirtilen hakların ırk, renk, cinsiyet, dil, din, siyasal ya da başka fikir, ulusal ya da toplumsal köken, mülkiyet, doğum ya da başka bir statü bakımindan herhangi bir ayrım gözetilmeksizin uygulanmasinı taahhüt ederler.

3. Gelişmekte olan ülkeler, insan haklarını ve kendi ulusal ekonomilerini dikkate alarak[vurgu yazar tarafindan yapılmıştır], bu Sözleşme'de tanınan ekonomik hakları hangi ölçüde yabancılara da vereceklerini belirleyebilirler.

Kişiler kendilerini tam olarak gerçekleştirebilmek ve potansiyellerini yansitabilmek için yeme, giyinme, barınma, ĕgitim, evlenme, sosyal güvenlik ve sağlık gibi sosyal haklara; sendikal haklar, çalışma hakkı, ücretli tatil yapma hakkı, yaşlılar, muhtaçlar, engelliler, kimsesiz çocuklar ve sosyal güvencesi olmayanlar gibi hassas grupların ya da kişilerin insanlık onuruna yakışır derecede bir hayat sürmesi için asgari bir yaşam standartları sağlayan ekonomik haklara (Donnelly, 1986: 607)ve toplumsal hayata tam anlamıla katılabilmek için kültürünü yaşama, kendi dil, din, etnik ve felsefi özelliklerini yaşatma ve geliştirmeve yaşam tarzı gibi kültürel haklara ihtiyaç duyarlar.

\subsection{3. Üçüncü Kuşak Haklar ya da Uzlaşma Hakları}

Üçüncü kuşak haklar özellikle 1970'li yıllarda eski sömürge toplumlarının bağımsızlığını kazanmasıyla sayıları artan, kapitalist Batı ve Sosyalist ikinci dünya ülkeleri dışında kalan kimisine göre üçüncü dünya olarak tanımlanan ülkelerin önemsediği daha çok uzlaşma hakları olarak da bilinen kolektif haklardır (Algan, 2004: 124-125). Farklı şekillerde bağımsızlıkları engellenmiş toplumların bu hakkını kazanmasını öngören ve temelde ABD Başkanı Wilson ilkelerine dayanan milletlerin kendi kaderini tayin etme hakkı (Uluslararası Sosyal, Ekonomik ve Kültürel Haklar Sözleşmesi ve Uluslararası Sivil ve Siyasal Haklar Sözleşmesi; madde 1); bu hakka bağlı olarak doğal kaynaklarını işletme hakkı (Uluslararası Sosyal, Ekonomik ve Kültürel Haklar Sözleşmesi (1976) ve Uluslararası Sivil ve Siyasal Haklar Sözleşmesi (1976); madde 1);gelecek nesilleri ve doğayı dikkate almadan ekonomik büyümeyi hedef alan kalkınma sonucu tahrip olan çevreyi koruma amaçlı sürdürülebilir kalkınma, temiz ve sağlıklı bir çevre hakkı (Afrika İnsan ve Topluluk Hakları Şartı ( 1981), BM Kalkınma Hakkı Deklarasyonu (1986), BM Yerel Halkların Hakları Deklarasyonu (2007), Stokholm Konferansı (1972) ve Rio Deklarasyonu (1992) ; sömürgecilik ve küresel ekonomik sistem neticesinde giderek fakirleşen başta Güney yarım küre olmak üzere diğer ülkelerin bu dezavantajını kısmen de olsa gidermeyi amaçlayan kalkınma hakkı (BM Kalkınma Hakkı Deklarasyonu (1986); iç ve dış çatışmalarla giderek fakirleşen ve artan insan hakları ihlallerini engellemek için barış hakkı (BM Barış Hakkı Deklarasyonu (1984), bunlardan bazılarıdır (Cornescu, 2009). 
Yukarıda sözü geçen hakların tamamı farklı zamanlarda fakat birçoğu 1970'lerden sonra yapılan uluslararası insan hakları belgeleriyle düzenlenmişlerdir. Yaşadıkları sorunların çoğunun kaynağı ve sebebi olarak gelişmiş dünyayı gören üçüncü dünya ülkeleri, bu sorunların çözülmesi için onların da sorumlu tutulmaları gerektiğini ileri sürmüşlerdir. Küreselleşme, küresel fakirlik, küresel tehditler, çevre kirliliği gibi insan hakları ihlallerine neden olan fakat ülkelerin tek başına çözüm bulmasında sorun yaşadığı alanların işbirliği ile çözülmesi ve vatandaşlarının temel hak ve özgürlüklerini sağlayamayan ülkelerde insan haklarının korunması için uluslararası insan hakları belgeleri uluslararası topluma sorumluluklar yüklemektedir (Algan, 2004: 146-147). Evrensel İnsan Hakları Beyannamesi 28. maddesinde "Herkesin bu Bildirgede ileri sürülen hak ve özgürlüklerin tam olarak gerçekleşebileceği bir toplumsal ve uluslararası düzene hakkı vardır" denerek, küresel sorunların ortak bir çaba ile çözülebileceği ve çözülmesi gerektiği ifade edilmektedir.

\subsubsection{Dördüncü Kuşak Haklar ya da İletişim Hakları}

Kitle iletişim ve bilişim teknolojilerindeki gelişmeler beraberinde yeni sorunlar ve yeni ihtiyaçlar doğurmuştur. İnternet, cep telefonları, sosyal iletişim ağları gibi teknolojiler insanların günlük hayatının önemli bir parçası haline gelmiştir. $\mathrm{Bu}$ teknolojilerin sınırlandırılması ya da yasaklanması başta gelişmiş ülkeler olmak üzere, dünyanın birçok bölgesinde günlük hayatı olumsuz etkileyecek ve insanların manevra alanlarını daraltacaktır. İfade özgürlügü, haberleşme ve iletişim hakları, örgütlenme hakkı gibi bazı haklar bugün bu teknolojilerle doğrudan bağlantılıdır. Bu teknolojiler aynı zamanda bir ülkedeki insan hakları ihlallerinin yayılması ve dünya kamuoyunun oluşturulması için de önemli araçlardır. Arap baharında sosyal iletişim ağlarının oynadığı önemli ve hayatı rolü bütün dünya fark etmiştir. $\mathrm{Bu}$ nedenle kimisi bu devrimlere haklı olarak "Twitter devrimleri" demektedir.

Kitle iletişim hakkının bu etkili kullanımı çoğu zaman otoritelerin hoşuna gitmemektedir ve otoriteler bu hakkı sinırlama yoluna gitmektedirler. Twitter, Facebook ve kişisel blogların yasaklanması baskıcı yönetimlerin dünyada sık sık başvurduğu bir yöntemdir.

Bazıları dördüncü kuşak haklar olarak daha çok genetik mühendisliği ile ilgili hakları dikkate almaktadır. Bazıları ise, bu kategoride gelecek nesilleri ilgilendiren insanlığın ortak varlıkları gibi hakları kabul etmektedir. Başkaları ise, uzayın keşfi ve uzaydan elde edilecek yararları bu kategoriye almaktadır(Cornesvcu, 2009).

Dördüncü kuşak hak kategorisi birçok analist tarafından eleştirilmekte ve literatürde fazla rağbet görmemektedir. Yöneltilen eleştirilerin başında, bu kategoride ifade edilen hakların birinci kuşak haklar arasında tanımlanan ifade özgürlüğü kapsamına girdiği ileri sürülmektedir. Diğer eleştiriler ise, karmaşık, sınırları belli olmayan ve çoğunun birbiriyle bağlantılı olmadığı iddia edilmektedir. $\mathrm{Bu}$ nedenle, yeni yazılmış birçok insan hakları kitabında bile dördüncü kuşaktan bahsedilmemektedir.

Özetle, insan haklarını daha iyi anlamak ve analiz edebilmek için, bu haklar birtakım temellere dayandirılarak kategorize edilmelidir, fakat bu kategorilerin net çizgilerle birbirinden ayrıldığını söylemek zordur. Zira negatif olarak kabul edilen her hakkın kısmen de pozitif yanları vardır, tersi de geçerli olabilmektedir. Örneğin, adil yargılanma hakkı, negatif bir hak olarak kabul edilmektedir, fakat bu hakkın sağlanabilmesi için mahkeme binası, hâkim 
ve savcının sağlanması gerekmektedir. Bu durumda, adil yargılanma için devletin pozitif bir yük yüklenmesi gerekir. Bu nedenle, bu hakkın saf negatif bir hak olduğunu söylemek zordur. Benzer bir durum diğer birçok haklar için de geçerlidir.

Yükseköğretimin insan hakkı olup olmadığı ve insan hakkıysa isteyen herkese sağlanması gerekip gerekmediği sorusuna gelirsek;

a) Yükseköğretim insan hakları düzenlemelerinde eğitim hakkının bir parçası olarak değerlendirildiğinden evrensel bir insan hakkı olduğu ileri sürülebilir.

b) Pozitif bir hak ya da sosyal, ekonomik ve kültürel bir hak olarak kabul edildiğinden sağlanması toplumların ya da ülkelerin gücü ve kaynaklarıyla sınırlıdır. Bu nedenle, eşit erişilebilir olduğu ve sağlanması ayrımcılığa tabi tutulmadığı sürece, adil koşullar çerçevesinde sınırlı sayıda kişinin faydalanması, onun hak doğasına zarar vermez. Başka bir ifade ile yükseköğretim hakkının sağlanması, toplumların ekonomik gücüne ve altyapısına bağlıdır. Bu nedenle, farklı ülkelerde farklı düzeylerde sağlanması bu hakkın ihlali anlamına gelmez.

\section{Hak-Temelli Bir Yükseköğretim}

Yukarıda ifade edildiği gibi, uluslararası insan hakları belgelerinde tanımlanan eğitim hakkı, kişilerin sadece eğitime ulaşmasını kapsamamakta, aynı zamanda verilecek eğitimin içeriğinin de insan haklarına uygunluğunu öngörmektedir. EİHB 26. maddesinin 2. fikrası bu durumu şöyle ifade etmektedir: " Eğitim, insan kişiliğinin tam geliştirilmesine, insan haklarına ve temel özgürlüklere saygıyı güçlendirmeye yönelik olmalıdır. Eğitim, bütün uluslar, rrklar ve dinsel gruplar arasında anlayış, hoşgörü ve dostluğu yerleştirmeli ve Birleşmiş Milletlerin barışı koruma yolundaki etkinliklerini güçlendirmelidir". Avrupa İnsan Hakları Sözleşmesi, 1. Ek protokol 2. maddesi de verilecek eğitimin ana-babanın dini ve felsefi inançlarına aykırı olamayacağını belirtmektedir: "Hiç kimse eğitim hakkından yoksun bırakılamaz. Devlet, eğitim ve öğretim alanında yükleneceği görevlerin yerine getirilmesinde, ana ve babanın bu eğitim ve öğretimin kendi dini ve felsefi inançlarına göre yapılmasını sağlama haklarına saygı gösterir". Eğitimde ayrımcılığı yasaklarken uluslararası insan hakları belgeleri, bilimsel, eleştirel, kapsayıcı, çoğulcu, katılımcı ve insan kişiliğinin tam gelişmesi için bir ortamın oluşturulmasını desteklemektedir. Uluslararası hukuka göre, bu bağlayıcı insan hakları düzenlemelerine taraf olan ülkeler, bu belgelerde tanımlanan evrensel, bilimsel ve insan odaklı eğitim modelini uygulamakla yükümlüdürler (Akyeşilmen, 2014: 5-6). İnsan hakları belgelerinin öngördüğü eğitim modeline literatürde hak-temelli eğitim de denmektedir (OSCE, 2008: 7).

\subsection{Hak-Temelli Bir Eğitim Modeli: PANEL Analizi}

İnsan hakları temelli bir eğitim modelinin özellikleri büyük oranda benzerlikler taşımasına rağmen, detaylarda bazen kişiden kişiye ve kurumdan kuruma farklılıklar gösterebilmektedir (Downs, 2009: 4). UNICEF (2007: 10-11) insan haklarının temel özelliklerini göz önüne alarak hak temelli bir eğitimin ilkeleri arasında evrensellik, devredilemezlik, bölünmezlik, birbiriyle ilişkili olması, eşitlik, ayrımcılığın olmaması, katılımcılık ve kapsayıcılık, güçlendirme, hesap verebilirlik ve hukukun üstünlüğünü saymaktadır. Akyeşilmen de (2014:8-13) insan hakları belgelerinde belirtilen eğitimin 
özelliklerini göz önüne alarak, hak-temelli bir eğitimi katılımcılık (participation), hesap verebilirlik ya da şeffaflık (accountability), ayrımcılığın olmaması (non-discrimination), güçlendirme (empowerment) ve insan haklarıyla doğrudan ilişkilendirme (linkages to human rights) kavramlarının İngilizce baş harflerine denk gelen PANEL Analizi ile formüle etmiştir.

PANEL Analizi bileșenleri kısaca tanımlanacaksa; katılımcılık, müfredattan okutulacak kitaplara, ders işleme yönteminden eğitim politikalarına kadar, eğitim sürecinin tüm safhalarında başta öğrenci ve öğretmen olmak üzere aile, eğitim kurumları, eğitim STK'ları ve bürokrasi dahil tüm eğitim paydaşlarının karar alma mekanizmasında etkili olmasını öngörmektedir (Jennifer-Morgan, 2006: 340-348).Hesap verebilirlik ya da şeffaflik ise, eğitimde tüm süreçlerin şeffaf olmasını ve eğitim kurumları ile eğiticilerin demokratik topluma karşı sorumlu olmasını gerektirmektedir. Ayrımcılı̆̆ın olmaması ilkesi, eğitimin herkese eşit bir şekilde açık ve ulaşılabilir olmasını ve herkesin kişisel ve kültürel ihtiyaçlarına göre düzenlenmesini zorunlu kılmaktadır. Güçlendirme ise, eğitimin insanların kendi kaderini şekillendiren eylemleri tasarlama firsatı vermesini başka bir ifade ile, insanların kendi kaderini kontrol edebilmesi için eğitimin bir araç olmasını hedefler(Benedek, 2012: 253;Atanasio, 2002). Hak-temelli bir eğitimde güçlendirme, bireyleri özgür kılmalı, özgür, eleştirel ve bilimsel düşünmesine zemin hazırlamalı (Chrisp, 2013:16)ve endoktrinasyondan uzak olmalıdır. PANEL Analizinin son bileșeni olan insan haklarıyla ilişskilendirme ise, kişilerin bireysel, entelektüel ve profesyonel kapasitelerinin geliştirilmesi için insanlık onurunu korumayı amaçlayan temel hak ve özgürlüklerin sağlanması, insan haklarına saygının pekiştirilmesi ve evrensel bir insan hakları kültürünün oluşmasına katkı sağlamayı amaçlamaktadır(Akyeşilmen, 2014:8-13).

Yükseköğretimde hak-temelli bir eğitim, ancak akademik özgürlüğün sağlandığ1 bilimsel özerkliğe sahip bir üniversite ile mümkündür. Üniversitelerde akademik özgürlüğün ve kurumsal özerkliğin ihlali, toplumlarda sosyal, ekonomik, kültürel ve siyasal alanda onarımı zor sorunlara ve büyük maliyetlere neden olabilir. Buna karşılık genel olarak eğitim istikrarlı, barışçıl ve demokratik bir toplumun oluşmasında ve özelde yükseköğretim bütün boyutlarıyla kalkınma süreçlerinde anahtar bir role sahiptir (Magna-Charta, 1999).

\subsection{Akademik Özgürlük}

Akademik özgürlük dünyanın her tarafinda yüksek öğretimin olmazsa olmaz şartı olarak ifade edilmesine rağmen, tanımları, sınırları, yansımaları ve uygulamaları birbirinden farklı olduğundan (Karran, 2007: 291) literatürde birbiriyle çelişen ve çakışan bir takım argüman ve tartışmalara neden olmuştur. Akademik özgürlük kavramı zamanla tanımı ve mahiyeti değişen dinamik bir kavramdır aynı zamanda. Eski çağlarda daha çok öğreticilerin bask1 görmeden öğretme özgürlüğü ve öğrencilerin öğrenme özgürlüğü ile sınırlı iken, 19. yüzyılda buna özgür araştırma eklenmiştir ve daha sonra ifade ve örgütlenme özgürlüklerini de kapsayacak bir anlam kazanmıştır (Altbach, 2001: 206). UNESCO'nun 11 Kasım 1997 tarihinde kabul ettiği "Yükseköğretimde Eğitici Personelin Statüsüne İlişkin Tavsiye Raporu"na göre, akademik özgürlük "hiçbir sınırlamaya tabi tutulmadan öğretme ve tartışma özgürlüğü, araştırma yapma ve elde edilen sonuçları yayma ve yayınlama özgürlüğü, çalıştıkları kurum ya da sistem ile ilgili görüsslerini dile getirme özgürlüğü, kurumsal sansürden ve baskıdan uzak, mesleki ve akademik kurumlara katılım özgürlüğü hakkı" olarak tanımlanmıştır. Buna göre, "bütün yükseköğretim personeli, hiçbir temelde ayrımcılığa tabi olmaksızın ve devlet ya da herhangi başka bir gücün baskısından korkmadan görevlerini yerine getirme hakkına sahiptirler" (UNESCO, 1997: par.27). Tanımda görüldüğü gibi, diğer 
hak ve özgürlüklerin yanında, akademik özgürlük; öğretme özgürlüğü, tartışma özgürlügü, araştırma özgürlüğü, ifade özgürlüğü, yayın yapma özgürlüğü ve örgütlenme özgürlüğünü kapsamaktadır. Tavsiye raporu, sadece akademik özgürlük tanımı yapmamakta, aynı zamanda eğitim, öğretim ve araştırma hakkının akademik özgürlük ve kurumsal özerklikle sağlanabileceğine de vurgu yapmaktadır. Daha önemlisi, dünyada barış ve istikrarın sağlanabilmesi için yükseköğretimde özgürce verilecek bir barış eğitimi ve insan haklarına saygıyı gerekli görmektedir (UNESCO, 1997). ILO-UNESCO ortak çalışması ise, kurumsal özerkliği de bütün yükseköğretim personelinin ve kurumlarının görevlerini yerine getirebilmesi için bir önşart olarak görmekte ve akademik özgürlügün kurumsal bir formu olarak tanımlamaktadır (ILO-UNESCO, 2012: iv).

Özetle, üniversite misyonunun temelinde, akademik özgürlüğün olduğu ve bu özgürlüğün gelişmiş bir yükseköğretim, araştırma ve eğitim için olmazsa olmaz bir şart olduğu ve yükseköğretimin temel bir değeri olduğu konusunda yaygın bir kanaat vardır (Altbach, 2001: 205). Bu nedenle, akademisyenlerin ve yükseköğretim karar alıcılarının akademik özgürlüğün anlamını, içeriğini, yasal çerçevesini, güncel boyutlarını (Poch, 1993:5) ve etkilerini bilmeleri bilimsel gelişme ve toplumsal kalkınma için son derece önemlidir.

Yükseköğretimde akademik özgürlüğün tanımı ve sınırlarının tartışmalı olmasına rağmen, gerekliliği konusunda dünya genelinde bir konsensüs vardır. Zira akademik özgürlük bilimsel araştırma yapabilme, toplumsal değişim, dönüşüm ve demokratik bir toplumsal düzenin oluşmasına katkı sağlama, insan haklarına saygıyı pekiştirme ve üniversiteden beklenen görevin yerine getirilmesi için önemli bir araç olduğu kadar gerekli bir unsurdur (Seggie ve Gökbel, 2014: 12-13). Akademik özgürlük aynı zamanda üniversitelerde insan hakları-temelli bir eğitim ve öğretim için, özgür düşünce ve demokratik fikirlerin rahatça yayılması için ve sınırlamaya tabi olmadan bilimsel ve akademik araştırma ve yayınlar için de gerekli bir unsurdur.

Akademik özgürlüğün yükseköğretimde ve toplumsal dönüşümde bu denli önemli ve hayati olmasına rağmen, gerek uluslararası bilimsel toplantılarda ve gerekse literatürde az tartışılan bir kavram olması, düşünülmesi ve çözüm bulunması gereken bir konudur(Altbach, 2001: 206).Internet çağında ve küreselleşme sürecinde akademik özgürlüklerin korunmasının bilimsel ve toplumsal kalkınma için temel bir unsur olduğu konusunda yaygın bir kanaatin varlığı yukarıda vurgulanmıştı. $\mathrm{Bu}$ çerçevede, akademik özgürlüğün korunması ve yaygınlaştırılabilmesi için günümüzde yükseköğretim kurumlarının yapması gereken bir takım düzenlemeler mevcuttur (Poch, 1993:80-81).

Yukarıda elde edilen veriler 1şı̆̆ında akademik özgürlüğün yaygınlaşması, korunması ve yerleşebilmesi için üniversitelerin aşağıdakileri yapmasında büyük bir yarar olduğu sonucuna varılmıştır:

1- Öncelikle internet sayfalarının başında ve görünür bir şekilde uluslararası akademik özgürlük standartları çerçevesinde tasarlanmış açık, net ve kapsamlı bir akademik özgürlük bildirgesi koymalıdırlar.

2- Yükseköğretim kurumlarının karar alıcıları akademik özgürlüğün yasal parametreleri ile ilgili temel bir bilgiye sahip olmalı ve bu özgürlükleri korumanın yükseköğretimin temel değeri olduğu konusunda farkındalık sahibi olmalıdırlar. 
3- Yükseköğretim kurumlarının akademik özgürlükle ilgili politikalarının belirlenmesinde başta akademisyenler olmak üzere tüm yükseköğretim paydaşları aktif bir rol almalidir.

4- Yükseköğretim kurumlarında akademik özgürlük ile ilgili konular hakkında konferanslar, seminerler ve çalıştaylar düzenlenmeli ve bu konudaki akademik yayınlara ağırlık verilmelidir.

5- Akademik özgürlüğün yükseköğretimin temel bir değeri olduğu bilinci, bilgisi ve anlayışı akademik personelden idari personele, öğrencilerden yardımcı personele bütün bir yükseköğretim camiasında canlı tutulmalıdır.

6- Akademik özgürlüğün korunması ve geliştirilmesi için başta örgütlenme özgürlügünün kullanılması olmak üzere yerel, ülkesel, bölgesel ve uluslararası akademik ve mesleki örgütlerde aktif olunmalı ve onlarla yoğun bir ilişki geliştirilmelidir. Bu sayede akademik özgürlügün uluslararası koruma mekanizmalarına ulaşımı sağlanabilecektir.

7- Son olarak, akademik özgürlüğün akademisyenden öğrenciye, yöneticiden araştırmacıya yükseköğretimin tüm paydaşları için korunması gereken bir değer olduğu bilinci ve anlayışı yaygınlaştırılmalıdır. Böyle bir farkındalık sayesinde özgürlük alanı olması gereken üniversitelerde bilimsel gelişme önünde bir engel olan hiyerarşik ilişkiler engellenebilecektir.

\section{SONUÇ}

Literatürde yükseköğretimin temel bir insan hakkı olup olmadığı konusu tartışmalı bir mesele iken, hukuki anlamda birçok uluslararası insan hakları belgelerinde evrensel bir insan hakkı olarak düzenlenmiştir. Yükseköğretimin, evrensel bir insan hakkı olarak düzenlenmesi, özünde herkese açık olması ve isteyen kişilerin herhangi bir önşarta bağlı olmaksızın bu haktan yararlanmasını öngörmektedir. Fakat ekonomik, sosyal ve kültürel haklar gibi bazı uluslararası insan haklarının sağlanması ivedi ve otomatik değildir. Bu hakların sağlanması ilgili ülkelerin ekonomik ve altyapı imkânlarıyla sınırlı olabilmektedir. Eğitim hakkı da, özellikle yükseköğretim, bu çerçevede değerlendirildiğinden, bu haktan yararlanmak özünde herkesin hakkı iken, pozitif bir hak olması hasebiyle toplumun imkânları çerçevesinde herkese açık ve ulaşılabilir olması şartıyla yani firsat eşitliği ilkesi çerçevesinde sağlanabilmektedir. Kısacası, bu kısa çalışmada varılan bulgular ışı̆̆ında yükseköğretim;

a) uluslararası insan hakları belgelerinde evrensel bir insan hakkı olarak düzenlenmiştir;

b) fakat uygulaması toplumların imkanları dahilinde herkese açık ve eşit ulaşılabilir olması şartına bağlanmıştır. 
Eğitim hakk1 şüphesiz sadece insanlara herhangi bir eğitimin sağlanması ile sınırlı değildir. $\mathrm{Bu}$ hak, verilecek eğitimin içeriğinin ve yönteminin de insan haklarına uygun olmasını, insan hak ve özgürlüklerine saygıyı geliştirmesini ve küresel barışa hizmet etmesini amaçlamalıdır. Böyle bir eğitimin sağlanabilmesi için ise, yükseköğretim kurumlarında akademik özgürlük ve kurumsal özerkliğin sağlanması ve bunun yasal güvence altına alınması esastır. Daha önemlisi, bu özgürlüklerin uluslararası koruma mekanizmalarından yararlanması önemli bir güvence olacaktır. Akademik özgürlüğün özü, akademisyenlerin, öğrencilerin ve araştırmacıların fikirlerini korkusuzca ifade edebilmeleridir (Downs, 2009: 16-17). Akademik özgürlük konusunda akademisyenlerin ve akademik kurumların hassas olması, bu konuda farkındalığı canlı tutması ve bilimsel araştırmalara ağırlık vermesi bu hak ve özgürlüklerin korunmasına büyük bir yarar sağlayacaktır. 


\section{KAYNAKÇA}

AKYEŞİLMEN, Nezir (2014). "Uluslararası İnsan hakları Düzenlemeleri ve Eğitim: Eğitime Hak temelli Bir bakış", Milli Eğitim, Yı1: 43, Sayı: 201, ss. 5-16.

ALGAN, Bülent (2004). "Rethinking 'Third generation' Human Rights", Ankara Law r Review, Vol.1, No.1, ss. 121-155.

ALTBACH, Philip, G. (2001). "Academic freedom: International Realities and Challenges", Higher Education, Kluwer Academic Publishers, ss.205-219. http://link.springer.com/article/10.1023/A:1026791518365\#page-1 (09.04.2015).

BENDEK, Wolfgang (2012). Understanding Human Rights, Neuer Wissenschaftlicher Verlag, Graz.

CHRİSP, Jillian (2013). Human Rights Education A Manual for National Human Rights Institutions, Asia Pacific Forum of National Human Rights Institutions, Sydney.

CONESCU, Adrian Vasillas, (2009). "The Generations of Human's Rights", Dny Prava, Days of Law: the Conference Proceedings, 1. edition, Masaryk University, Brno. http://www.law.muni.cz/sborniky/dny_prava_2009/files/prispevky/tvorba_prava/Corn escu_Adrian_Vasile.pdf( 12.04.2015).

DONELLY, Jack (1986), "International Human Rights: A Regime Analysis", International Organization, 40 (3), ss. 599-639.

DOWNS, Donald, A (2009). Academic Freedom: What It Is, What It Isn't, and How to Tell the Difference, John W. Pope Center for Higher Education Policy, Raleigh. http://www.popecenter.org/acrobat/AcademicFreedom.pdf (12.04.2015).

GLOBALHIGHERED (2011). "Tertiary Education: A Global Report", https://globalhighered.wordpress.com/2011/11/26/tertiary-education-a-global-report/ (26.03.2015).

HAULE, Romuald, R. (2006). "Some Reflections on the Foundation of Human Rights : Are Human Rights an Alternative to Moral Values?", Max Planck Yearbook of United Nations Law, Vol.10, ss.367-395.

ILO-UNESCO (2012).Joint ILO-UNESCO Committee of Experts on the Application of the Recommendations concerning Teaching Personnel (CEART), UNESCO-ILO, Geneva, http://www.right-to-education.org/sites/right-to-education.org/files/resourceattachments/ILO $\% 20 \% 26 \% 20$ UNESCO_The_status_of_academic_freedom_and_insti tutional_autonomy_worldwide_2012_en.pdf( 02.04.2015).

JENNIFER-Morgan, Swift. (2006), "What Community Participation in Schooling Means: Insights from Southern Ethiopia”, Harvard Educational Review, Cil.76, No.3, ss.339-368.

KARA, Uğur (2014). Temel İnsan Hakları Bilgisi-I, ( 5. bask1),Anadolu Üniversitesi Yayını, Eskişehir. 
KARRAN, Terence (2007). "Academic Freedom in Europe: A Preliminary Comparative Analysis", Higher Education Policy, 20, ss. 289-313.

MADİGAN, Janet Holl (2004). Being Human, Beeing good: The Source and Summit Universal Human Rights, Dissertation Submitted to the University of Maryland, http://drum.lib.umd.edu/bitstream/1903/1753/1/umi-umd-1729.pdf( 12.04.2015).

MAGNA-CHARTA (1999), "The Bologna Declaration of 19 June 1999", http://www.magnacharta.org/resources/files/BOLOGNA_DECLARATION.pdf (02.04.2015).

MCCOWAN, Tristan (2012). "Is there a universal right to education", Bitish Journal of Educational Studies, 60 (2), ss.111-128.

OSCE, Council of Europe, UNHCHR and UNESCO (2008). Human Rights Education in the School Systems of Europe, Central Asia and North America: A Compendium of Good Practice, Poligrafus Andrzej Adamiak, Warsaw.

OSLER, Audrey H. (2012). "Higher education, human rights and inclusive citizenship", Tehmina Basit ve Sally Tomlinson,Social Inclusion and Higher Education, The Policy Press, Bristol.

PAVEL, Nicolae (2012). "Classification of Fundamental Rights and Freedoms- a diachronic Approach and Current Trends", Challenges of the Knowledge Society ( conf. paper), Jourlib Journal, http://www.jourlib.org/paper/2954050\#.VSrcUvmsXT8 (12.04.2015).

POCH, Robert K. (1993). Academic Freedom in American Higher Education: Rights, Responsibilities and Limitations, Ashe-Eric Higher Education Reports- Rep. No.4, The George Washington University, Washington D.C.

SASTRY, T.S.N. (2011). Introduction to Human Rights and Dutries, University of Pune, Pune.

SEGGİE, Fatma Nevra ve Gökbel, Veysel (2014). Geçmişten Günümüze Akademik Özgürlük, SETA, Ankara.

UNESCO (1997)." Recommendation concerning the Status of Higher-Education Teaching Personnel ", http://www.unesco.org/education/docs/recom_e.html (02.04.2015).

UNICEF (2007). A Human Rights Based Approach to Education for All, UNICEF, New York. 